\title{
Implikasi Hukum Terhadap Penggunaan Duplikasi Nama Persekutuan Komanditer Yang Belum Pernah Didaftarkan Ke Pengadilan Negeri Menurut Permenkumham Nomor 17 Tahun 2018
}

\section{Farzan Sirajuddin}

Magister Kenotariatan Fakultas Hukum, Universitas Islam Indonesia Yogyakarta Indonesia Jln. Cik Di Tiro No. 1, Yogyakarta Indonesia farzansirajuddin@gmail.com

\begin{tabular}{|c|c|}
\hline Key Word: & Abstract \\
\hline Duplication in name; & Permenkumham Number 17 of 2018 on Registration of Limited Partnerships, Firm \\
\hline registrar of the & Partnerships, and Civil Partnerships contains technical rules regarding \\
\hline district court & registration, registration of amendments to Articles of Association, registration of \\
\hline & dissolution, and records of registration. The problem being researched is what steps \\
\hline & should be taken to comply with these rules if there are similarities in names, while \\
\hline & $\begin{array}{l}\text { on the other hand, many legal actions have been taken? This study uses a juridical- } \\
\text { normative research method and a statutory approach. This study concludes, the }\end{array}$ \\
\hline & Notary as the attorney of the Petitioner can take the following steps: first, providing \\
\hline & lanation of the consequences of the rule that there should be no duplication of \\
\hline & $\begin{array}{l}\text { the deed, especially in the premise section, emphasizing that the CV has been } \\
\text { established long before the enactment of Permenkumham Number } 17 \text { of } 2018 \text { but } \\
\text { has not yet been registered to the Registrar of the District Court. }\end{array}$ \\
\hline
\end{tabular}

Kata-kata Kunci:
Duplikasi nama;
kepaniteraan
pengadilan
negeri

Abstrak
Permenkumham Nomor 17 Tahun 2018 Tentang Pendaftaran Persekutuan
Komanditer, Persekutuan Firma, dan Persekutuan Perdata berisi aturan
teknis mengenai pendaftaran, pendaftaran perubahan anggaran dasar,
pendaftaran pembubaran, dan pencatatan pendaftaran. Permasalahan yang
diteliti, bagaimana langkah yang harus dilakukan untuk menyesuaikan
dengan aturan tersebut jika terdapat kesamaan nama, sementara di sisi lain
sudah banyak melakukan perbuatan hukum? Penelitian ini menggunakan
metode penelitian yuridis-normatif dan pendekatan perundang-undangan.
Penelitian ini menyimpulkan, Notaris sebagai kuasa dari Pemohon dapat
melakukan langkah-langkah sebagai berikut., pertama, memberi penjelasan
mengenai konsekuensi dari aturan tersebut bahwa tidak boleh ada
penggunaan duplikasi nama. Kedua, mengajukan penggunaan nama CV
melalui sistem. Ketiga, dalam akta tersebut, khususnya pada bagian premis
ditegaskan bahwa CV tersebut sudah berdiri lama sebelum berlakunya
Permenkumham Nomor 17 Tahun 2018, namun belum didaftarkan di
Kepaniteraan Pengadilan Negeri.

\section{Pendahuluan}

Bentuk usaha persekutuan komanditer atau CV banyak dipilih oleh pengusaha skala kecil menengah. Selain proses pendiriannya relatif mudah karena tidak memerlukan pengesahan oleh negara, juga tidak ada syarat modal minimum untuk mendirikan CV. ${ }^{1}$ Kitab Undang-Undang Hukum Dagang (KUHD) hanya mengatur

1 Purwosutjipto, Pengertian Pokok Hukum Dagang Indonesia; Bentuk-Bentuk Perusahaan, Djambatan, Jakarta, 1987, hlm. 40-53 dalam Yetty Komalasari Dewi, Pemikiran Baru tentang Persekutuan Komanditer (CV): Studi 
tentang definisi dari CV saja dan tidak mengatur tentang tata cara pendirian, pendaftaran, atau pengumumannya, sehingga CV dimungkinkan untuk didirikan secara lisan sepakat para pihak saja. ${ }^{2}$ Menurut Yahya Harahap, pendirian Persekutuan Komanditer pada dasarnya tidak jauh berbeda dengan persekutuan Firma. Umumnya pendirian dilakukan dengan akta Notaris kemudian didaftarkan di kepaniteraan pengadilan negeri tempat di mana Persekutuan Komanditer tersebut berkedudukan kemudian mengumumkan ikhtisar akta pendirian dalam Berita Negara Republik Indonesia. ${ }^{3}$

Pendirian CV bisa dilakukan secara tertulis atau secara lisan, baik dengan akta otentik maupun di bawah tangan. Tidak ada keharusan untuk melakukan pendaftaran dan pengumuman dalam Berita Negara Republik Indonesia dalam pendirian CV. Namun dalam mewujudkan kepastian hukum akta pendirian CV sebaiknya dibuat oleh di hadapan Notaris sebagaimana diatur dalam Pasal 22 KUHD. Akan tetapi, ketiadaan akta demikian tidak dapat dikemukakan untuk merugikan publik/ pihak ketiga. Pada prakteknya, di Indonesia telah menunjukkan suatu kebiasaan bahwa pendirian CV didasarkan pada akta otentik Notaris, didaftarkan di Kepaniteraan Pengadilan Negeri, dan diumumkan dalam Tambahan Berita Negara Republik Indonesia. ${ }^{4}$

Pemerintah melalui Menteri Hukum dan Hak Asasi Manusia (Menkumham), telah menerbitkan Peraturan Menteri Hukum dan Hak Asasi Manusia Republik Indonesia (Permenkumham) Nomor 17 Tahun 2018 tentang Pendaftaran Persekutuan Komanditer, Persekutuan Firma, dan Persekutuan Perdata. Hal ini sebagai tindak lanjut dari Peraturan Pemerintah Nomor 24 Tahun 2018 tentang Pelayanan Perizinan Berusaha Terintegrasi Secara Elektronik. ${ }^{5}$ Sejak diterbitkannya peraturan tersebut, segala bentuk perubahan legalitas baik permohonan pendaftaran pendirian maupun perubahan anggaran dasar CV, Firma, dan Persekutuan Perdata ditujukan kepada Menkumham melalui Sistem Administrasi Badan Usaha (SABU). Berdasar Pasal 1 ayat (5) Permenkumham Nomor 17 Tahun 2018, SABU adalah Pelayanan jasa teknologi informasi badan usaha secara elektronik yang diselenggarakan oleh Direktorat Jenderal Administrasi Hukum Umum. Beberapa hal yang diatur sebagian besar mengenai proses administrasi pendirian dan perubahan anggaran dasar badan usaha non badan hukum. ${ }^{6}$

Salah satu hal yang diatur dalam Permenkumham Nomor 17 Tahun 2018 adalah mengenai pengaturan penggunaan nama, yang mengatur larangan penggunaan nama yang sama dengan CV lain yang sudah terdaftar. Hal ini terdapat dalam Pasal 5 ayat (2) huruf b, bahwa nama CV, Firma, dan Persekutuan Perdata sebagaimana dimaksud pada ayat (1) yang diajukan harus memenuhi persyaratan ditulis dengan huruf latin dan

Perbandingan KUHD dan Wvk serta Putusan-Putusan Pengadilan Indonesia dan Belanda, Disertasi, Fakultas Hukum, Program Doktoral Pascasarjana Universitas Indonesia, Jakarta, 2011, hlm. 1

2 Lihat Pasal 22 KUHD.

${ }^{3}$ Yahya Harahap, Hukum Perseroan Terbatas, Ctk. Ketiga, Sinar Grafika, Jakarta, 2011, hlm. 17-18.

${ }^{4}$ Ketut Caturyani Maharni Partyani, "Pertentangan Norma dalam Pengaturan Pendaftaran dan Pendirian Comanditaire Vennootschap (CV)", Jurnal Vyavahara Duta, Vol. XIV, No. 1, Maret, 2019, hlm. 71-72.

${ }^{5}$ Kementerian Hukum dan Hak Asasi Manusia, Naskah Akademik Rancangan Undang-Undang tentang Badan Usaba, 2018, hlm. 5.

${ }^{6}$ Ibid. 
belum dipakai secara sah oleh CV, Firma, dan Persekutuan Perdata lain dalam Sistem Administrasi Badan Usaha.

Mendasarkan pada aturan tersebut lantas menjadi pertanyaan, jika ada suatu CV yang menggunakan nama tertentu dan sudah didirikan serta beroperasi sejak lama, tetapi belum pernah didaftarkan pada Kepaniteraan Pengadilan Negeri untuk memenuhi asas publisitas. Sedangkan di sisi lain terdapat suatu CV yang berbeda yang kegiatan usahanya pun berbeda dan memiliki nama serupa, namun sudah menyesuaikan legalitasnya dengan ketentuan Permenkumham Nomor 17 Tahun 2018. CV yang terakhir disebut otomatis sudah mendapat persetujuan penggunaan nama dari Menteri Hukum dan Hak Asasi Manusia. Lalu apakah bisa CV yang pertama disebut untuk mempertahankan atau setidaknya tetap menggunakan nama tersebut yang sudah terlanjur dipakai serta eksis dan atau setidaknya tetap beroperasi menggunakan nama CV tersebut karena sudah terlanjur berhubungan hukum dengan pihak kedua. Hal tersebut berbeda dengan CV yang sudah didirikan sebelum berlakunya Permenkumham Nomor 17 Tahun 2018, namun sudah didaftarkan di Kepaniteraan Pengadilan Negeri. CV demikian dapat melakukan penyesuaian dengan melakukan pencatatan pendaftaran sesuai Ketentuan Peralihan yang diatur dalam Pasal 23 Permenkumham Nomor 17 Tahun 2018. CV tersebut tetap bisa menggunakan nama yang sudah dipakainya sejak dulu.

\section{Rumusan Masalah}

Berdasarkan persoalan di atas maka, dapat dirumuskan dua masalah, pertama, apakah konsekuensi hukum apabila suatu CV yang sudah didirikan sejak lama namun belum didaftarkan di Pengadilan Negeri menggunakan nama yang sama dengan CV yang sudah melakukan penyesuaian Permenkumham Nomor 17 Tahun 2018? Kedua, bagaimana langkah yang harus dilakukan oleh Notaris sebagai kuasa dari pihak Pemohon untuk menyesuaikan dengan Permenkumham Nomor 17 Tahun 2018 bagi CV yang sudah berdiri dan sudah beroperasi namun belum pernah didaftarkan ke Pengadilan Negeri?

\section{Tujuan Penelitian}

Tujuan penelitian ini adalah pertama, untuk mengetahui tentang konsekuensi hukum apabila terdapat suatu CV yang sudah didirikan sejak lama, namun belum didaftarkan di Pengadilan Negeri menggunakan nama yang sama dengan CV sudah melakukan penyesuaian Permenkumham Nomor 17 Tahun 2018. Kedua, untuk mengetahui bagaimana langkah yang dilakukan oleh Notaris sebagai kuasa dari pihak Pemohon apabila terdapat CV yang ingin melakukan penyesuaian atas Permenkumham Nomor 17 Tahun 2018 namun belum pernah melakukan pendaftaran di Pengadilan Negeri sebagai syarat publisitas.

\section{Metode Penelitian}

Penelitian ini berjenis yuridis-normatif dengan menggunakan pendekatan peraturan perundang-undangan (statute approach). Sumber data primer berupa Undang- 
Undang Dasar Negara Republik Indonesia Tahun 1945, Kitab Undang-Undang Hukum Perdata, Kitab Undang-Undang Hukum Dagang, Peraturan Presiden Nomor 91 Tahun 2017 tentang Percepatan Pelaksanaan Berusaha, Peraturan Pemerintah Nomor 24 Tahun 2018 tentang Pelayanan Perizinan Berusaha Terintegrasi Secara Elektronik, Permenkumham Nomor 17 Tahun 2018 tentang Pendaftaran Persekutuan Komanditer, Persekutuan Firma, dan Persekutuan Perdata, dan Undang-Undang Nomor 2 Tahun 2014 tentang Jabatan Notaris. Sedangkan sumber data sekunder dari buku, sumber-sumber atau dokumen resmi, yaitu jurnal, tesis, dan segala bentuk studi kepustakaan yang mendukung penelitian yang bersangkutan. Kemudian penelitian ini menggunakan pendekatan studi lapangan dengan mengambil data wawancara subyek hukum yang relevan dan berwenang.

\section{Hasil Penelitian dan Pembahasan}

\section{Konsekuensi Hukum Kesamaan Nama antara CV Lama yang Belum Didaftarkan di Pengadilan Negeri dengan CV Baru yang Melakukan Penyesuaian Permenkumham Nomor 17 Tahun 2018}

Pendaftaran perseroan Firma merupakan suatu keharusan mendasarkan pada Pasal 23 ayat (1) KUHD. Ketentuan pasal tersebut bersifat imperatif karena tujuannya memaksa untuk mematuhi norma. Pendaftaran dilakukan oleh para sekutu Firma, dengan cara menyerahkan petikan akta pendirian dalam bentuk otentik. ${ }^{7}$ Menurut Pasal 25 KUHD maksud dari pendaftaran di pengadilan adalah agar setiap orang dapat melihat akta pendirian yang memuat ketentuan-ketentuan anggaran dasar yang bersangkutan, dan bahkan setiap orang berhak meminta kepada Pengadilan Negeri turunan dari akta pendirian yang memuat anggaran dasar tersebut. Demikian jelas pendaftaran itu tujuannya sebagai pengumuman kepada khalayak. Demikian pula maksud diharuskannya diumumkan dalam Berita Negara Republik Indonesia sebagaimana dalam Pasal 28 KUHD. 8

Berdasarkan hasil wawancara dengan narasumber Notaris, pendaftaran ke Kepaniteraan Pengadilan Negeri bukanlah syarat sah berdirinya suatu CV. Syarat sah berdirinya suatu $\mathrm{CV}$ adalah ketika sudah ditandatanganinya akta pendirian oleh para pihak atau pendiri. Bahkan ada yang mengatakan secara lisan pun juga bisa, namun untuk bukti tertulis sebaiknya dibuat menggunakan akta Notaris. Ketika para pendiri sudah menandatangani akta pendirian $\mathrm{CV}$, maka sudah secara sah diakui sebagai badan usaha. Hal ini berbeda halnya dengan badan hukum Perseroan Terbatas, ada mekanisme yang harus ditempuh. Misalnya wajib melakukan pengecekan nama terlebih dahulu, kemudian pembuatan akta pendirian, penyetoran modal, lalu pengesahan dari Kemenkumham. Barulah saat ditandatanganinya surat keputusan oleh Kemenkumham tersebut, maka lahirlah badan hukum Perseroan Terbatas. ${ }^{9}$

\footnotetext{
${ }^{7}$ Lihat Pasal 23 ayat (2) KUHD

8 Ibid.

9 Wawancara dengan Fatir Tashin Syafiq, Notaris di Kabupaten Sleman, bertempat di kantor Notaris, 15 September 2020 .
} 
Tanggung jawab Notaris sebagai pejabat umum meliputi tanggung jawab profesi Notaris itu sendiri yang berhubungan dengan akta. Sehubungan dengan kewenangannya tersebut, Notaris dapat dibebani tanggung jawab atas perbuatannya dalam membuat akta otentik. Tanggung jawab Notaris sebagai pejabat umum meliputi tanggung jawab profesi Notaris itu sendiri yang berhubungan dengan akta, diantaranya:10 (a) tanggung jawab Notaris secara perdata terhadap akta yang dibuatnya, $(b)$ tanggung jawab Notaris secara pidana atas akta yang dibuatnya, $(c)$ tanggung jawab Notaris secara administrasi atas akta yang dibuatnya.

Jika berbicara mengenai tanggung jawab Notaris dalam hal suatu CV dibuat oleh dan atau di hadapannya, maka Notaris dapat menggunakan asas praduga sah. Akta Notaris sebagai produk dari pejabat publik, maka penilaian terhadap akta Notaris harus dilakukan dengan Asas Praduga Sah (Vermoeden ven Rechtmatigheid) atau Presumptio Iustae Causa. Asas ini dapat dipergunakan untuk menilai akta Notaris, yaitu akta Notaris harus dianggap sah sampai ada pihak yang menyatakan akta tersebut tidak sah. ${ }^{11}$ Sedangkan beberapa hal yang diatur dalam Permenkumham Nomor 17 Tahun 2018 yaitu mengenai perizinan berusaha. Berdasar Pasal 1 ayat (4) dijelaskan Perizinan Berusaha adalah pendaftaran yang diberikan kepada Pelaku Usaha untuk memulai dan menjalankan usaha dan atau kegiatan dan diberikan dalam bentuk surat/keputusan atau pemenuhan persyaratan dan atau komitmen. Kemudian dalam Pasal 1 ayat (5) dijelaskan, "Perizinan Berusaha Terintegrasi Secara Elektronik atau Online Single Submission yang selanjutnya disebut OSS adalah Perizinan Berusaha yang diterbitkan oleh Lembaga OSS untuk dan atas nama menteri, pimpinan lembaga, gubernur, atau bupati/wali kota kepada Pelaku Usaha melalui sistem elektronik yang terintegrasi."

Dalam hal suatu CV yang sudah didirikan sejak lama, namun belum pernah didaftarkan di Kepaniteraan Pengadilan Negeri ternyata menggunakan nama yang sama dengan CV lain yang sudah menyesuaikan legalitasnya dan tercatat dalam SABU sesuai Permenkumham Nomor 17 Tahun 2018, tidak diatur akbiat hukumnya secara tegas dalam peraturan tersebut. Permenkumham Nomor 17 Tahun 2018 hanya mengatur mengenai ketentuan larangan penggunaan kesamaan nama yang diakomodir dalam Pasal 5 ayat (2) huruf b dan akibat hukum dari Pasal 5, yaitu diatur dalam Pasal 8 Permenkumham Nomor 17 Tahun 2018. Tersebut pada Pasal 8, "Dalam hal nama tidak memenuhi persyaratan pengajuan dan pemakaian nama CV, Firma, dan Persekutuan Perdata sesuai dengan ketentuan sebagaimana dimaksud dalam Pasal 5, Menteri dapat menolak nama CV, Firma, dan Persekutuan Perdata tersebut secara elektronik."

Konsekuensi hukumnya jika nama CV tersebut sudah dipakai oleh CV lain, maka CV yang belum didaftarkan di Kepaniteraan Pengadilan Negeri tersebut adalah ditolak oleh Menteri melalui SABU. CV tersebut tidak boleh menggunakan nama yang sama dengan yang sudah digunakan oleh CV lain dan harus mengganti atau menggunakan nama lain, jika Pemohon mengajukan permohonan pengajuan nama melalui SABU sesuai ketentuan Pasal 5 Permenkumham Nomor 17 Tahun 2018. Kemudian CV tersebut juga

${ }^{10}$ Kunni Affah, "Tanggung Jawab dan Perlindungan Hukum Bagi Notaris Secara Perdata Terhadap Akta yang Dibuatnya”, Jurnal Lex Renaissance, Vol 2, No. 1, Januari 2017, hlm. 151.

${ }^{11}$ Habib Adjie, Kebatalan dan Pembatalan Akta Notaris, Refika Aditama, Bandung, 2011, hlm. 85-86. 
tidak dapat menggunakan pencatatan pendaftaran akta pendirian CV-nya sesuai Ketentuan Peralihan Pasal 23 ayat (1) dan ayat (2), karena sudah berdiri dan beroperasi lama sebelum diberlakukannya Permenkumham Nomor 17 Tahun 2018 agar tetap dapat menggunakan atau mempertahankan namanya. Hal ini dikarenakan yang dapat menyesuaikan pencatatan pendaftaran sesuai dengan ketentuan Pasal 23 tersebut adalah CV yang sudah berdiri dan beroperasi lama, namun khusus yang sudah didaftarkan di Kepaniteraan Pengadilan Negeri. Konsekuensi teknis apabila suatu CV tidak menyesuaikan legalitasnya dengan Permenkumham Nomor 17 Tahun 2018 adalah tidak dapat masuk ke dalam sistem SABU, sehingga tidak terjangkau atau tidak tercatat oleh Permenkumham Nomor 17 Tahun 2018.

\section{Langkah Notaris sebagai Kuasa dari Pihak Pemohon untuk Menyesuaikan dengan Permenkumham Nomor 17 Tahun 2018}

Di dalam Pasal (2) Permenkumham Nomor 17 Tahun 2018 dijelaskan bahwa pendaftaran CV, Firma, dan Persekutuan Perdata meliputi pendaftaran akta pendirian, pendaftaran perubahan anggaran dasar; dan pendaftaran pembubaran. Secara umum, terdapat dua ruang atau kamar dalam hal pendaftaran tersebut, yaitu pertama, kamar pendaftaran pendirian serta perubahan anggaran dasar, dan kedua, kamar pencatatan pendaftaran badan usaha non badan hukum CV, Firma, dan Persekutuan Perdata. Pendaftaran diatur dalam Pasal 4 sampai dengan Pasal 21 Permenkumham Nomor 17 Tahun 2018. Menu pendaftaran berfungsi untuk melakukan pendaftaran CV yang belum terdaftar, baik secara manual ataupun secara elektronik dan telah melakukan pengajuan nama CV pada sistem. Setelah Pemohon melakukan pengajuan nama CV, langkah selanjutnya adalah melakukan pendaftaran CV. Sedangkan menu pencatatan pendaftaran berfungsi untuk mencatatkan CV yang sebelumnya telah didaftarkan dan tercatat secara manual pada Pengadilan Negeri, namun belum mendaftar secara elektronik. Untuk pencatatan pendaftaran, Pemohon tidak perlu mengajukan permohonan nama terlebih dahulu. ${ }^{12}$

Dalam hal suatu CV belum pernah didaftarkan di Kepaniteraan Pengadilan Negeri untuk memenuhi asas publisitas, tetapi sudah melakukan hubungan hukum dengan pihak kedua, maka hal tersebut masih bisa dijalankan sepanjang tidak dipermasalahkan oleh pihak kedua tersebut. namun, apabila itu menjadi permasalahan di antara mereka, maka CV tersebut harus mendaftarkan ulang atau membuat CV baru sesuai Permenkumham Nomor 17 Tahun 2018. Selanjutnya, setelah jadi baru disampaikan kepada rekanan pihak kedua tersebut untuk pembaharuan nama subyek hukum. ${ }^{13}$ Hal ini juga sesuai dengan ketentuan Pasal 1338 KUHPerdata yang berbunyi, "Semua perjanjian yang dibuat secara sah berlaku bagi undang-undang bagi mereka yang membuatnya."

Untuk CV yang sudah didirikan sejak lama, dan sudah didaftarkan di Kepaniteraan Pengadilan Negeri untuk memenuhi asas publisitas, Notaris dapat

\footnotetext{
12 Wawancara dengan Essy Wulan Agustin, Notaris di Kabupaten Sleman, bertempat di Kantor Notaris, 21 September 2020.

${ }^{13}$ Ibid.
} 
melakukan penyesuaian Permenkumham Nomor 17 Tahun 2018 dengan menggunakan pencatatan pendaftaran, mengacu pada Bab III tentang Pendaftaran Perubahan Anggaran Dasar CV, Firma, dan Persekutuan Perdata, khusunya pada Pasal 15 sampai dengan Pasal 19. Kemudian hal lain yang terpenting dari pencatatan pendaftaran adalah adanya format pendukung berupa akta pendirian atau perubahan anggaran dasar CV yang sudah didaftarkan di Kepaniteraan Pengadilan Negeri. Hal ini berfungsi sebagai dokumen pendukung yang akan diunggah ke SABU.14 Hal inilah yang membedakan suatu CV agar dapat melakukan pencatatan pendaftaran pada SABU.

Untuk CV yang sudah didirikan sebelum berlaku Permenkumham Nomor 27 Tahun 2018, namun belum pernah didaftarkan di Kepaniteraan Pengadilan Negeri dapat dilakukan hal sebagai berikut,15 pertama yang harus dilakukan Notaris jika mendapat penghadap atau klien demikian adalah menanyakan terlebih dahulu kepada para sekutu, apakah mereka benar-benar sudah cocok dan ingin tetap mempertahankan nama CV yang sudah digunakan tersebut atau tidak masalah jika harus mengganti nama CV tersebut. Kemudian hal selanjutnya adalah memberi penjelasan bahwa konsekuensi dari berlakunya Pemenkumham Nomor 17 tahun 2018 adalah tidak boleh ada kesamaan penggunaan nama antar badan usaha non badan hukum. Setelah itu memberi penjelasan terkait dengan segala akibat hukum yang timbul kepada CV yang bersangkutan dan pihak lain apabila CV tersebut mengganti namanya. Kedua, adalah memesan nama terlebih dahulu, seperti langkah awal pendirian CV baru pada SABU. Hal ini didasarkan pada Pasal (4) Permenkumham Nomor 17 Tahun 2018, "Permohonan pendaftaran sebagaimana dimaksud pada Pasal 3 harus didahului dengan pengajuan nama $\mathrm{CV}$, Firma, dan Persekutuan Perdata." Pemesanan nama CV bisa dengan menggunakan nama CV yang sudah lama digunakan, tapi belum pernah didaftarkan di Kepaniteraan Pengadilan Negeri. Jika nama tersebut disetujui oleh SABU karena belum dipakai oleh CV lain dan belum mendapat persetujuan Menteri, maka dapat dilanjutkan ke proses selanjutnya. Namun, jika pengajuan nama tersebut ditolak oleh SABU, maka Pemohon dapat menambahkan dan atau mengganti sebagian dari suku kata nama CV yang bersangkutan. Kemudian jika pengajuan nama diberikan persetujuan oleh Menteri, berlaku ketentuan Pasal 7 Permenkumham Nomor 17 Tahun 2018.

Langkah berikutnya yang dapat diambil oleh Notaris apabila pengajuan permohonan nama disetujui oleh Menteri adalah membuat akta perubahan anggaran dasar CV serta menyesuaikan maksud dan tujuan dari anggaran dasar tersebut sesuai dengan Peraturan Kepala Badan Pusat Statistik Nomor 19 Tahun 2017 tentang Perubahan Atas Peraturan Kepala Badan Pusat Statistik Nomor 95 Tahun 2015 tentang Klasifikasi Baku Lapangan Usaha Indonesia. Hal yang harus ditekankan adalah status dari CV yang belum pernah mendaftar di Kepaniteraan Pengadilan Negeri tersebut pada bagian premis dalam akta perubahan anggaran dasar tersebut. Notaris dapat membuat perubahan anggaran dasar manakala permohonan pengajuan nama disetujui oleh Menteri melalui SABU.16

\footnotetext{
14 Wawancara dengan Essy Wulan Agustin, Ibid,

15 Wawancara dengan Fatir Tashin Syafiq, Op. Cit.

${ }^{16}$ Ibid.
} 
Produk Notaris adalah produk keperdataan, yaitu merupakan bukti formil (apa yang ditunjukkan kepada Notaris). Artinya akta otentik yang memuat kebenaran formil, yaitu sesuai dengan apa yang diberikan para pihak kepada Notaris. Pada dasarnya seorang Notaris tidak bertanggung jawab dan tidak dapat dipertanggung jawabkan secara hukum terhadap kebenaran materiil. Oleh karena itu, Notaris dalam menjalankan tugas jabatan dan tanggung jawabnya harus menggunakan prinsip kehati-hatian. Dalam hal demikian terjadi, Notaris dapat menanganinya dengan membuat akta perubahan anggaran dasar dan mempersiapkan penggantian dan atau penambahan suku kata nama $\mathrm{CV}$ tersebut, kemudian menekankan dalam hal penjelasan pada bagian premis. Hal itu juga merupakan kesalahan dan tanggung jawab pendiri atau pengurus $\mathrm{CV}$, bukan Notaris. 17

Dalam akta perubahan anggaran dasar tersebut, Notaris dapat lebih menekankan pada bagian premis yang menerangkan bahwa CV tersebut sudah didirikan sejak lama namun belum pernah didaftarkan di Kepaniteraan Pengadilan Negeri. Pembuatan perubahan anggaran dasar mengacu pada ketentuan Pasal 38 UUJN tentang anatomi akta. Salah satu bagian penting yang haris ditekankan dalam akta perubahan anggaran dasar tersebut adalah pada bagian premis. Premis berisikan mukadimah atau suatu uraian/redaksi yang merupakan pengantar sebelum masuk ke isi akta. ${ }^{18}$

Dalam hal demikian, Notaris dapat menambahkan redaksi berupa kalimat di dalam premis yang menegaskan atau menyatakan, "Para pihak terlebih dahulu menerangkan bahwa CV ... sudah didirikan dan beroperasi sejak lama sebelum berlakunya Permenkumham Nomor 17 Tahun 2018, dibuktikan dengan akta pendirian Anggaran Dasar CV ... Nomor ... Tanggal ... Tahun ... yang dibuat di hadapan Tuan/ Nyonya ... Notaris di Kota/ Kabupaten ..."; "Bahwa CV ... belum pernah didaftarkan di Kepaniteraan Pengadilan Negeri setempat sejak pertama kali didirikan, sehingga tidak ada pencatatan di Pengadilan Negeri setempat dan belum memenuhi asas publisitas"; "Bahwa berdasar hal tersebut, CV ... hendak menyesuaikan legalitasnya berdasar ketentuan Permenkumham Nomor 17 Tahun 2018 dengan segala konsekuensi hukum yang timbul dari aturan tersebut."

Fungsi penegasan dalam premis tersebut adalah usaha untuk menjamin hubungan hukum dengan pihak kedua. Dikarenakan CV tersebut sudah lama didirikan, maka sudah banyak melakukan hubungan hukum dengan pihak lain berupa perjanjian, perikatan, kerja sama, dan lain sebagainya. Hal ini agar CV tersebut tidak banyak mengubah perjanjian dengan pihak lain dikarenakan namanya berubah. ${ }^{19}$ Walaupun kemudian sistem dalam sistem SABU tetap menolak permohonan penggunaan nama, setidaknya dalam anggaran dasar sudah ditegaskan dalam premis, sehingga pihak yang berkepentingan dapat mengetahui hal tersebut.

Dalam hal permohonan pendaftaran badan usaha, pengajuan penggunaan nama diproses secara otomatis oleh sistem SABU. Dalam database SABU terdapat berbagai

17 Wawancara dengan Rio Kustianto Wironegoro, Notaris di Kota Yogyakarta, bertempat di kantor Notaris, 9 September 2020.

${ }^{18}$ Mulyoto, Perjanjian: Tehnik, Cara Membuat, dan Hukum Perjanjian yang Harus Dikuasai, Cakrawala Media, Yogyakarta, 2012, hlm. 4.

${ }_{19}$ Wawancara dengan Essy Wulan Agustin, Op. Cit. 
nama yang sudah dicatatkan serta disetujui oleh Menteri. Jadi, jika terdapat kesamaan nama, SABU akan otomatis menolak nama yang belum terdaftar dan mendapat pengesahan. Namun, jika proses pemesanan nama disetujui, permohonan pendaftaran pendirian CV dilakukan dengan cara mengisi Format Pendaftaran berdasar ketentuan Permenkumham Nomor 17 Tahun 2018, khususnya Pasal 10 ayat (3). Kemudian dalam Pasal 12 diatur mengenai dokumen pendukung yang harus dilengkapi oleh Pemohon berupa surat pernyataan secara elektronik dan juga mengunggah akta pendirian CV. Selanjutnya Pasal 13 Permenkumham Nomor 17 Tahun 2018 dijelaskan, "Pemohon wajib mengisi pernyataan secara elektronik yang menyatakan Format Pendaftaran dan keterangan mengenai dokumen pendukung telah sesuai dengan ketentuan peraturan perundang-undangan, serta Pemohon bertanggung jawab penuh terhadap Format Pendaftaran dan keterangan tersebut."

Berdasarkan keterangan dari narasumber yang penulis wawancarai, kesemuanya belum pernah mendapat klien atau penghadap yang mengalami kasus demikian, namun mereka mengatakan hal itu tidak menutup kemungkinan di kemudian hari akan ada penghadap yang mengalami hal seperti telah dijelaskan sebelumnya (CV yang sudah lama didirikan sebelum berlakunya Permenkumham Nomor 17 Tahun 2018, namun belum pernah didaftarkan di Kepaniteraan Pengadilan Negeri untuk memenuhi asas publisitas) dan meminta solusi pada Notaris. Maka, untuk mengantisipasi hal tersebut, dengan penelitian ini diharap mampu memberikan sumbangsih jawaban kepada Notaris dalam menyelesaikan hal demikian.

\section{Penutup}

Konsekuensi hukum apabila suatu CV yang sudah didirikan sejak lama namun belum pernah didaftarkan di Kepaniteraan Pengadilan Negeri menggunakan nama yang sama dengan CV yang sudah melakukan penyesuaian Permenkumham Nomor 17 Tahun 2018 adalah permohonan pengajuan nama CV yang belum pernah didaftarkan tersebut ditolak oleh Menteri melalui SABU jika mengajukan permohonan pengajuan nama melalui SABU. Dengan kata lain CV tersebut tidak terdaftar dan tidak tercatat di dalam sistem SABU, sehingga Pemerintah baik pusat maupun daerah tidak mengetahui legalitas CV tersebut. Sedangkan konsekuensi hukum terhadap pihak kedua adalah tidak ada jika tidak dipermaslahkan oleh para pihak, karena yang mengetahui adanya perikatan atau perbuatan hukum hanya para pihak. Terakhir konsekuensi hukum terhadap Pemerintah selaku pihak ketiga adalah CV tersebut tidak memiliki legal standing dalam hal legalitas serta tidak bisa atau kesulitan dalam mengurus perizinan yang diperlukan di kemudian hari.

Langkah yang dapat diambil oleh Notaris sebagai kuasa dari pihak pemohon untuk menyesuaikan dengan Permenkumham Nomor 17 Tahun 2018 ada dua cara, yaitu pertama melakukan proses seperti pendaftarn $\mathrm{CV}$ baru melalui SABU dengan cara memesan nama terlebih dahulu. Jika nama CV tersebut belum dipakai secara sah oleh CV lain dan disetujui oleh Menteri melalui SABU, maka langkah berikutnya adalah membuat perubahan anggaran dasar CV dan menyesuaikan maksud dan tujuan sesuai KBLI 2017 serta menambahkan keterangan dalam bagian premis mengenai eksistensi dan legalitas 
dari CV yang belum pernah didaftarkan di Kepaniteraan Pengadilan Negeri. Jika permohonan pengajuan nama ditolak, maka CV tersebut harus mengganti dengan menambah atau mengurangi suku kata dari nama yang lama untuk proses awal agar dapat masuk ke dalam SABU.

\section{Daftar Pustaka}

\section{Buku}

Habib, Adjie, Kebatalan dan Pembatalan Akta Notaris, Refika Aditama, Bandung, 2011.

Mulyoto, Perjanjian: Tehnik, Cara Membuat, dan Hukum Perjanjian yang Harus Dikuasai, Cakrawala Media, Yogyakarta, 2012;

Purwosutjipto, Pengertian Pokok Hukum Dagang Indonesia; Bentuk-Bentuk Perusahaan, Djambatan, Jakarta, 1987.

Yahya, Harahap, Hukum Perseroan Terbatas, Ctk. Ketiga, Sinar Grafika, Jakarta, 2011.

\section{Hasil Penelitian/Tugas Akhir}

Daniel Duha, Kepastian Hukum Akta Pendirian Perseroan Komanditer (Commanditaire Venootschap) yang Tidak Diumumkan Dalam Berita Negara Ditinjau Dari Kitab Undang-Undang Hukum Dagang, Tesis, Magister Kenotariatan, Universitas Sumatera Utara, Sumatera Utara, 2015.

Yetty Komalasari Dewi, Pemikiran Baru tentang Persekutuan Komanditer (CV): Studi Perbandingan KUHD dan Wvk serta Putusan-Putusan Pengadilan Indonesia dan Belanda, Disertasi, Fakultas Hukum, Program Doktoral Pascasarjana Universitas Indonesia, Jakarta, 2011.

\section{Jurnal}

Christin Sasauw, "Tinajuan Yuridis tentang Kekuatan Mengikat Suatu Akta Notaris", Jurnal Lex Privatum, Vol. III/ No. 1, 2015.

Ketut Caturyani Maharni Partyani, "Pertentangan Norma dalam Pengaturan Pendaftaran dan Pendirian Comanditaire Vennootschap (CV)", Jurnal Vyavahara Duta, Vol. XIV, No. 1, Maret, 2019.

Kunni Affah, "Tanggung Jawab dan Perlindungan Hukum Bagi Notaris Secara Perdata Terhadap Akta yang Dibuatnya", Jurnal Lex Renaissance, Vol 2, No. 1, Januari 2017.

\section{Peraturan Perundang-Undangan}

Kitab Undang-Undang Hukum Perdata

Kitab Undang-Undang Hukum Dagang

Peraturan Pemerintah Nomor 24 Tahun 2018 tentang Pelayanan Perizinan Berusaha Terintegrasi Secara Elektronik

Peraturan Menteri Hukum dan Hak Asasi Manusia Nomor 17 Tahun 2018 Tentang Pendaftaran CV, Firma, dan Persekutuan Perdata

\section{Sumber Data Elektronik}

Kementerian Hukum dan Hak Asasi Manusia, Naskah Akademik Rancangan UndangUndang tentang Badan Usaha, 2018. 


\section{Sumber Data Wawancara}

Wawancara dengan Essy Wulan Agustin, Notaris di Kabupaten Sleman, bertempat di Kantor Notaris, 21 September 2020.

Wawancara dengan Fatir Tashin Syafiq, Notaris di Kabupaten Sleman, bertempat di kantor Notaris, 15 September 2020;

Wawancara dengan Rio Kustianto Wironegoro, Notaris di Kota Yogyakarta, bertempat di kantor Notaris, 9 September 2020;

Wawancara dengan Ngadiya, Bagian Penyuluh Hukum, Kantor Wilayah Kementerian Hukum dan Hak Asasi Manusia Daerah Istimewa Yogyakarta, di Yogyakarta, 15 Oktober 2020. 